\title{
Density and fluctuations of a nest-pocket breeding population of the Treecreeper Certhia familiaris over a 28-year period
}

\author{
Tätheten och fluktuationerna hos en holkhäckande population trädkrypare Certhia \\ familiaris under 28 år
}

ANDERS ENEMAR \& KERSTIN WIKLANDER

Abstract

\begin{abstract}
The number of breeding Treecreeper pairs was estimated from 1982 to 2009 in a $2.7 \mathrm{~km}^{2}$ study area located in south-western Sweden $\left(57^{\circ} 39^{\prime} \mathrm{N} ; 12^{\circ} 4^{\prime} \mathrm{E}\right)$. Most of the area, which was provided with 205 man-made nest pockets, is covered by broad-leafed forest. The number of first clutches varied between 5 and 21 with an annual average of $14 \pm 4.2$ (SD) breeding pairs (CV 30\%). The density of breeding Treecreepers varied from 1.9 to 7.8 pairs $/ \mathrm{km}^{2}$ with a mean of $5.1 \pm 1.86$ pairs $/ \mathrm{km}^{2}$. The population did not show any statistically significant density trend over the 28 years. The between-year variation in the return rate of ringed adult females that bred after wintering was significantly negatively related to the temperature and precipitation means of the preceding winter.
\end{abstract}

Thus, fewer females returned after milder winters with higher precipitation. The statistical tests pertaining to the variation in the whole breeding population indicate that the species can cope with moderate fluctuations in winter weather, thus preventing significant changes in the number of breeders in the study area.

Anders Enemar, Kyrkvägen 18 U, 43530 Mölnlycke, Sweden.E-mail: a-enemar@hem.utfors.se

Kerstin Wiklander, Department of Mathematical Sciences, Chalmers University of Technology and University of Gothenburg, 41296 Gothenburg, Sweden

Received 4 November 2013, Accepted 14 April 2014, Editor: Dennis Hasselquist

\section{Introduction}

The density of a passerine bird population is generally a consequence of the reproductive success during the preceding breeding season and the survival rate prior to the new breeding season (e.g. Newton 1998). It will therefore fluctuate between years. Most studies on fluctuation patterns deal with breeding populations because their numbers are relatively easy to estimate compared to those of the non-breeding or floating populations. Much knowledge in this field emanates from numerous long-term studies on populations breeding in nest boxes that facilitate estimation of both the number of breeding pairs and the reproductive rate. In this type of studies, both resident and long-distance migrant species have been investigated and include the classical long-term studies that started in the early part of the twentieth century (e.g. Kluijver 1951, Perrins 1979). The present work is of a similar nature and concerns a local population of the Treecreeper Certhia familiaris breeding in manmade nest pockets.

The Treecreeper is a small resident insectivorous passerine that is double-brooded and fairly site tenacious. In Sweden it inhabits various kinds of woodland from coniferous to deciduous broadleaved forests. It naturally nests behind loosened bark and in similar crevices in tree trunks. The main aim of this study was to document the longterm fluctuation pattern of a breeding Treecreeper population in a study area equipped with special nesting facilities. The possible influence of a number of environmental factors, mainly the winter temperature and precipitation, on the density of the breeding pairs was investigated.

Long-term bird census work in the breeding season can provide information of general interest about the density and fluctuation pattern of populations. These population parameters will be reported here for a local Treecreeper population (see Figure 1 , showing the distribution of the breeding females in the study area in a season with almost maximum density). The results mainly concern the number of breeding pairs and the return rate of individually marked females after wintering. As the variation in other factors not included in this study such as food supply, fledgling production and predation pressure is unknown, it has not been possible to explain 


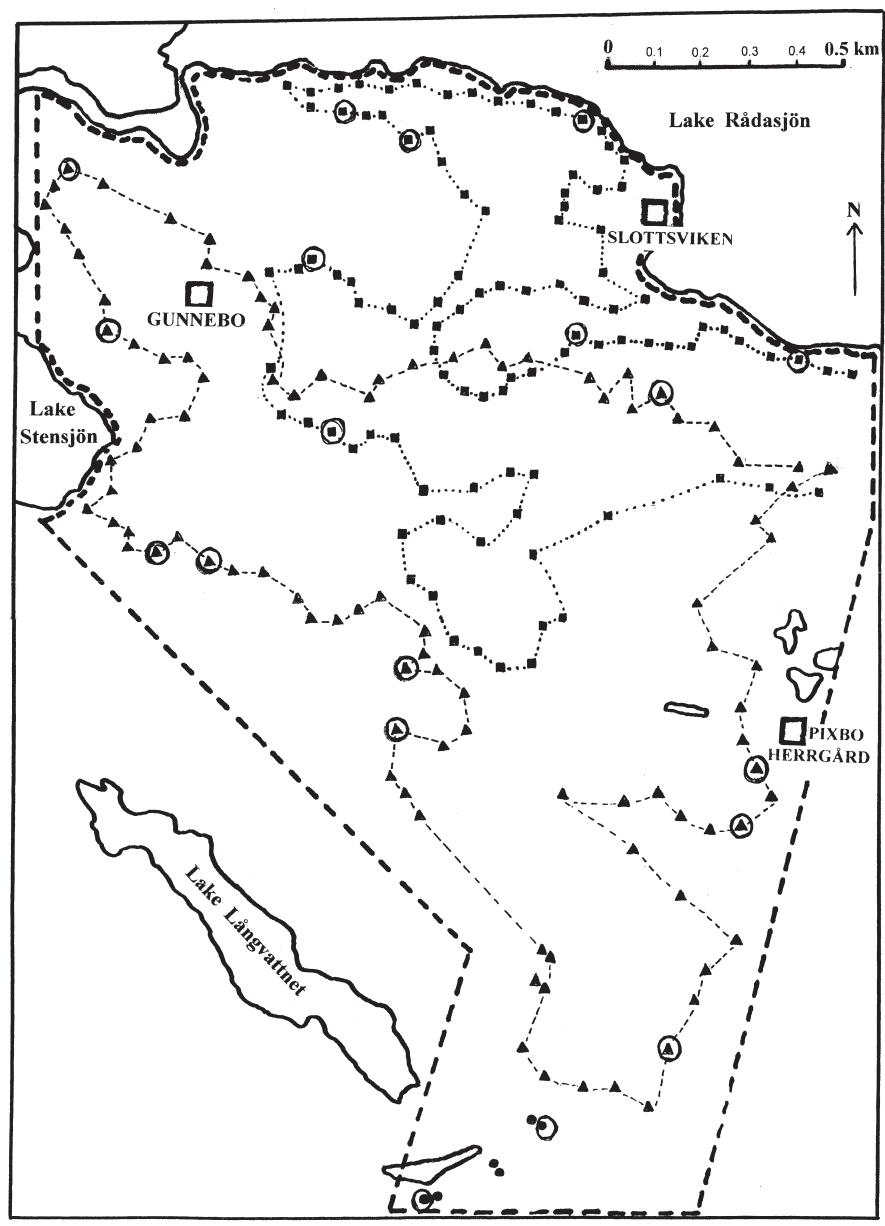

Figure 1. Sketch of the study area showing its position between Rådasjön, Stensjön and Långvattnet lakes. The broken line indicates the boundaries that include the 2.7 $\mathrm{km}^{2}$ study area. The three open squares represent three landmarks, namely the manor house of Gunnebo and the mansions of Slottsviken and Pixbo Herrgård. The sketch includes the two winding trails alongside which 99 nest pockets (filled squares) and 100 nest pockets (triangles), respectively, were erected. Together with another 6 pockets (filled circles) in the southern part of the area the total number of nest pockets was 205. The distribution pattern of occupied nest pockets (encircled) is exemplified by the 19 breeding pairs in 1999 (see Figure 2 , maximum number of breeding pairs was 21).

Skiss som visar provytans läge mellan $R a ̊-$ dasjön, Stensjön och Långvattnet. Dess gränser markeras av den streckade linjen, som omsluter en yta om $2,7 \mathrm{~km}^{2}$. De tre stora och öppna kvadraterna markerar lägena för tre riktpunkter, nämligen Gunnebo slott, samt herresätena Slottsviken och Pixbo Herrgård. Skissen visar två vindlande stigar. Längs den ena är 99 trädkryparfickor (små kvadrater) uppsatta och längs den andra 100 (små trianglar). Tillsammans med ytterligare 6 fickor (fyllda cirklar) $i$ sydligaste delen av provytan blir totalantalet trädkryparfickor 205. Fördelningen av bebyggda fickor (inringade) visas för år 1999 med 19 häckande par (se Figur 2, högsta antal hittills 21 par).

the often very dramatic fluctuations in the number of breeding pairs between adjacent seasons.

\section{Study area and methods}

The number of breeding Treecreeper pairs has been estimated annually from 1982 to 2009 in a study area, most of which is located on the Gunnebo recreation grounds $\left(57^{\circ} 39^{\prime} \mathrm{N} ; 12^{\circ} 4^{\prime} \mathrm{E}\right)$ between the small town of Mölndal and the village of Pixbo. Deciduous broad-leaved forest covers most of the area, with between 10 and $15 \%$ of open land mostly used for grazing. About $25 \%$ of the forest consists of mature coniferous plantations.

The study area has been richly equipped with man-made nesting facilities for the Treecreeper, so-called nest pockets spread all over the 2.7 $\mathrm{km}^{2}$ (Figure 1). Most likely all breeding female Treecreepers in the study area nest in these pock- ets (Enemar 2009), which are made of roofing felt and attached to the tree trunks with their entrance openings generally between $1.1 \mathrm{~m}$ and $1.4 \mathrm{~m}$ above ground. A piece of aluminium sheeting is attached to the occupied nest pockets to prevent Greater Spotted Woodpeckers Dendrocopos major from robbing the nests. The nest pockets are cleaned and the aluminium sheeting removed at the end of each breeding season. The number and location of the nest pockets have remained the same throughout the 28-year period. New pockets have replaced lost or damaged ones on the same tree or, when the original tree has been felled or blown over, on the nearest suitable trunk.

The number of clutches started within the 21 days following the laying of the season's first egg is deemed to represent the size of that year's breeding population and henceforth referred to as the "21-day population". This restriction is necessary 
to avoid counting twice those females that lay a replacement clutch when their first breeding effort has failed. The first clutch is mostly replaced after the 21-day period (Enemar 2009). This time limit is necessary when studying a non-colour-ringed population, as in the years 1982-1994 in our investigation. An analysis of the estimated 21-day populations of colour-ringed females (see below) reveals that only $3 \%$ (6 out of 180 ) of the clutches included in the 21-day period (i.e., broods counted as first broods) were in fact replacement broods. Hence, the risk of erroneously overestimating the size of the unmarked 21-day populations (in the years 1982-1994) is likely to be insignificant.

The nest pockets were inspected at various intervals depending on the demands of the season's research programme. To establish the size of the 21-day population, all pockets were visited at least once during the first 21 days, followed by one or two visits during the subsequent two weeks. From 1995 to 2009 (with the exception of 2004, 2006 and 2007), the inspections were combined with trapping the incubating or brooding females for colour ringing. Each female received a unique combination of three coloured rings as well as in most cases one metal ring.

Daily temperature and precipitation means were obtained from Säve airport (SMHI 1981-2009), which is situated about $15 \mathrm{~km}$ to the north of the study area. The temperature data are closely correlated with those of the study area $(\mathrm{r}=0.98$; Enemar 1997). However, the precipitation data of the two localities have not been compared. The winter temperature and precipitation means were calculated using the daily means of either the four winter months (November-February) or the six months of the winter half-year (October-March). Consequently, each winter period covers the turn of two calendar years. Thus, e.g. the 1995 breeding season is preceded by the winter of 1994/1995.

Since in some cases the identity of a bird was unknown, knowing whether or not there were correlations in the data set was an issue. Therefore, it was necessary to reduce the data to ensure that the requirements and assumptions of the independence of the statistical methods were fulfilled.

The statistical tests were kept to a minimum as the field data were relatively limited. Where applicable, special statistical tests are explained and commented on in the text.

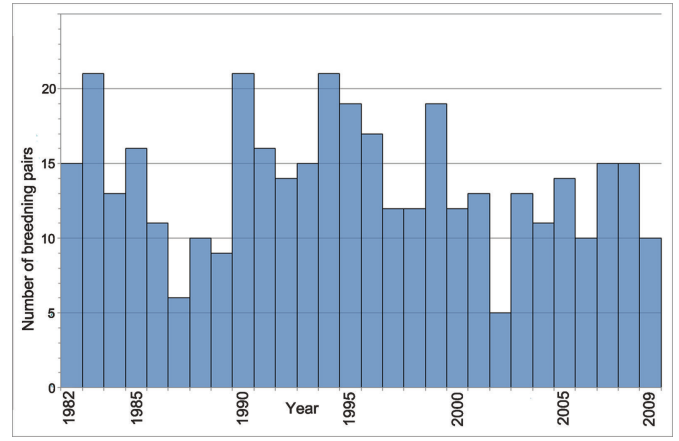

Figure 2. The annual numbers of breeding Treecreeper pairs (the 21-day populations, see text) in the study area from 1982 to 2009.

Staplarna visar antalet häckande trädkryparpar i provytan under perioden 1982 - 2009. Endast de häckningar, där värpningen påbörjats inom 21 dagar efter säsongens första trädkryparägg, är medräknade.

\section{Results and Discussion}

The size and fluctuations of the population

The size of the breeding Treecreeper population varied considerably during the course of the 28 seasons (Figure 2) with 5 and 21 pairs being the lowest and highest annual numbers, giving a yearly average of $14 \pm 4.2$ (SD) pairs. Three resident tit species, i.e., Great Tit Parus major, Blue Tit $C y$ anistes caeruleus and Coal Tit Periparus ater, have all shown fluctuation amplitudes of the same magnitude in long-term nest-box investigations (e.g. Perrins 1979). The size of the study area population revealed no statistically significant changing trend over the 28 years. The estimated slope in a model is -0.1 and the $p$-value 0.32 .

The nation-wide Swedish Bird Survey (SBS) found a decrease of between 20 and $30 \%$ in the Treecreeper population in the period 1976-2006 (Ottvall et al. 2009), mainly concentrated in the last 10 years. A close comparison between the results of the SBS and our investigation would be pointless because they differ markedly in terms of the size of the studied area, the census technique, the units counted and the proportion of habitat types surveyed. The Treecreepers in our study area almost exclusively inhabited deciduous woods. The SBS included coniferous forests where the density of resident co-inhabitants, such as the Willow Tit Poecile montana, Coal Tit and Goldcrest Regulus regulus, has decreased significantly (Ottvall et al. 2009, Ottosson et al. 2012). The decreasing trend in the Treecreeper population would probably become obvious first and foremost in coniferous 
forests and may be most pronounced in efficiently managed ones.

The results of the two investigations agree as regards the amplitude of the population fluctuation between years. The CV-value of the SBS results is $25 \%$ (calculated from the yearly SBS-indices received from $\AA$. Lindström), a figure of the same magnitude $(30 \%)$ as that of the present study population. The fluctuation pattern of the Treecreeper is similar to that of most other small-bird populations, which can halve or double in size between years (Figure 2) (Newton 1998).

\section{Population density}

The density of the breeding Treecreepers in the study area varied from about 1.9 to around 7.8 pairs $/ \mathrm{km}^{2}$ with a mean density of approximately 5 pairs $/ \mathrm{km}^{2}\left(5.1 \pm 1.86\right.$ pairs $\left./ \mathrm{km}^{2}\right)$. Similar density values have been reported elsewhere in southern Sweden (Ahlén \& Nilsson 1982, Angelstam in Kuitunen \& Helle 1988). The rich supply of breeding facilities and unoccupied space for territories in the study area (see Figure 1) did not lead to an increase in breeding density above its normal level, which according to a review published by Ottosson et al. (2012) is $8-12$ pairs $/ \mathrm{km}^{2}$ in southern Sweden. The somewhat lower density in our study area is probably a consequence of the fact that counting was restricted to Treecreeper pairs that started breeding at the beginning of the season (see Study area and methods). According to Glutz von Blotzheim \& Bauer (1993), about the same density has been reported in numerous investigations elsewhere in Europe. However, contrary to our results, the introduction of a surplus of artificial breeding facilities increased the breeding density many times over in some German study areas (Schönfeldt 1983, Schwerdtfeger 1987).

\section{Relationship between winter weather and size of the subsequent breeding population}

As a resident small passerine bird, winter survival of the Treecreeper is expected to be affected by local weather conditions (winter temperature and precipitation). More breeding pairs usually appear after a winter with favourable weather conditions, while fewer pairs are present after harsh winters. Generally, the species is fairly vulnerable to harsh weather, which also applies during the breeding season, because Treecreepers often postpone or interrupt egg laying during cold periods and desert clutches or young nestlings during days of heavy rain (Enemar 1995).

The seasonal temperature and precipitation means have been calculated for those 24 years (1986-2009) for which data on both these weather parameters are available. The temperature means $\left({ }^{\circ} \mathrm{C}\right)$ ranged from -2.7 to +3.9 for the November-February period and from -1.5 to +5.3 for the October-March period. The corresponding ranges for the precipitation means were $1.5-4.8 \mathrm{~mm}$ and $1.4-4.7 \mathrm{~mm}$, respectively.

The probability of the influence of the midwinter (November-February) temperature and precipitation on the size of the breeding population was tested statistically. For the population size, a Poisson regression was used with temperature and precipitation as so-called regressors. The result for temperature was a p-value of 0.221 , for precipitation 0.324 and for the interaction between temperature and precipitation 0.139 , which suggests that the species is adapted to cope with moderate fluctuations in the winter weather and this may prevent a significant decrease in population numbers. However, the fairly small sample size and the correlation between temperature and precipitation (colinearity) might reduce the power of this study. The results were also found to be insignificant when the two weather variables were tested in separate models (large p-values, above 0.7).

\section{Return rate of individual females}

When the breeding females have been colour ringed it is possible to investigate the extent to which they survive the winter and return to the study area to breed. The return rate can differ between years and might depend on, among other factors, the varying weather conditions during wintering. A considerable drawback in our study is the small number of investigated years. Colour ringing did not start until 1995 and due to circumstances beyond our control it was not possible in 2004, 2006 or 2007 , which means that only eleven years can be used in this analysis.

We were able to calculate the yearly mean return rates, as the number of ringed breeding females in the study area at the end of each breeding seasons was known as well as the number that returned to breed in the following spring (Table 1). When an individual female returned and bred for more than one season, only the first occasion was included in the analyses.

The possible relation between the weather conditions during both the short and long winter periods (see Study area and methods) and the return rate 
Table 1. Upper table part. Number of trapped and colour ringed breeding Treecreeper females in the study area during 1995 to 2009 and the percentage of returned ringed females of those ringed when breeding in the area in the preceding year. - Lower table parts. Mean temperature $\left({ }^{\circ} \mathrm{C}\right)$ and mean precipitation $(\mathrm{mm})$ of the long winter (October-March) and the short winter (November-February), respectively, during 1995 to 2009.

Övre delen av tabellen. Antal fångade och färgringmärkta honor i provytan under perioden 1995-2009 samt procentandelen återvända honor som ringmärkts året innan som häckare i provytan. - Nedre tabelldelarna. Medeltemperaturen $\left({ }^{\circ} \mathrm{C}\right)$ och medelnederbörden $(\mathrm{mm})$ för den längre vinterperioden (oktober-mars) respektive den kortare (november-februari) för åren 1995 till 2009.

\begin{tabular}{|c|c|c|c|c|c|c|c|c|c|c|c|c|c|c|c|}
\hline Year $A r$ & 95 & 96 & 97 & 98 & 99 & 00 & 01 & 02 & 03 & 04 & 05 & 06 & 07 & 08 & 09 \\
\hline $\begin{array}{l}\text { Number ringed } \\
\text { Antal ringmärkta } \\
\text { Number returned }\end{array}$ & 19 & 9 & 10 & 12 & 15 & 9 & 7 & 7 & 6 & 0 & 13 & 0 & 0 & 21 & 6 \\
\hline $\begin{array}{l}\text { Antal återvända } \\
\text { Per cent returned }\end{array}$ & - & 8 & 2 & 3 & 2 & 3 & 2 & 1 & 7 & 0 & - & 3 & - & - & 8 \\
\hline \% återvända & - & 42 & 22 & 30 & 17 & 20 & 22 & 14 & 100 & 0 & - & 23 & - & - & 38 \\
\hline $\begin{array}{l}\text { Mean temperature } \\
\text { Medeltemperatur }\end{array}$ & & & & & & & & & & & & & & & \\
\hline $\begin{array}{l}\text { Oct. - March } \\
\text { Nov. - Febr. }\end{array}$ & & $\begin{array}{r}0.7 \\
-1.7\end{array}$ & $\begin{array}{l}2.0 \\
0.1\end{array}$ & $\begin{array}{l}2.5 \\
2.1\end{array}$ & $\begin{array}{l}1.7 \\
0.1\end{array}$ & $\begin{array}{l}3.1 \\
2.4\end{array}$ & $\begin{array}{l}3.2 \\
2.2\end{array}$ & $\begin{array}{l}3.5 \\
1.7\end{array}$ & $\begin{array}{r}0.2 \\
-1.5 \\
\end{array}$ & $\begin{array}{l}2.0 \\
1.4\end{array}$ & $\begin{array}{l}2.6 \\
2.1\end{array}$ & $\begin{array}{l}2.4 \\
0.3\end{array}$ & $\begin{array}{l}5.4 \\
3.9\end{array}$ & $\begin{array}{l}4.1 \\
3.6\end{array}$ & $\begin{array}{l}3.3 \\
1.8 \\
\end{array}$ \\
\hline $\begin{array}{l}\text { Mean precipitation } \\
\text { Medelnederbörd }\end{array}$ & & & & & & & & & & & & & & & \\
\hline $\begin{array}{l}\text { Oct. - March } \\
\text { Nov. - Febr. }\end{array}$ & & $\begin{array}{l}1.3 \\
1.1\end{array}$ & $\begin{array}{l}2.7 \\
3.1\end{array}$ & $\begin{array}{l}2.1 \\
2.3\end{array}$ & $\begin{array}{l}3.1 \\
2.3\end{array}$ & $\begin{array}{l}3.1 \\
3.3\end{array}$ & $\begin{array}{l}3.5 \\
3.5\end{array}$ & $\begin{array}{l}3.1 \\
2.8\end{array}$ & $\begin{array}{l}1.7 \\
1.7\end{array}$ & $\begin{array}{l}2.3 \\
2.5\end{array}$ & $\begin{array}{l}2.9 \\
2.5\end{array}$ & $\begin{array}{l}2.7 \\
2.2\end{array}$ & $\begin{array}{l}4.7 \\
4.8\end{array}$ & $\begin{array}{l}3.5 \\
3.7\end{array}$ & $\begin{array}{l}2.3 \\
1.9\end{array}$ \\
\hline
\end{tabular}

of females was statistically investigated. A logistic regression was applied to analyse the simultaneous influence of temperature and precipitation on the probability of return. A model with the two explanatory variables, temperature and precipitation as well as their interaction was applied. The p-values were all greater than 0.1 , which was also the case when the insignificant interaction was excluded from the model. The short winter period values led to similar results, although the model fit was slightly poorer.

A drawback of these data is that the two explanatory variables, temperature and precipitation, have a high correlation $(\mathrm{r}=0.714$ and significant with $\mathrm{p}$ value 0.014 ). This fact makes the inference weaker with greater uncertainty in the parameter estimates in the full model that includes both explanatory variables and the interaction term. This could explain why the result failed to reveal any significant effects (see Table 2). However, correlated explanatory variables and a small sample size make the power very low. Therefore, claiming that neither temperature nor precipitation influences the probability of return is incorrect.

However, when the regressors (i.e., the explanatory variables temperature and precipitation) ap-

Table 2. Summary of the results from different models for Return rate.

Sammanfattning av resultat från olika modeller för återkomst.

\begin{tabular}{lccc}
\hline Model & $\begin{array}{c}\text { Estimate of the parameters } \\
\text { Parameterskattning }\end{array}$ & $\begin{array}{c}\text { Standard } \\
\text { error }\end{array}$ & p-value \\
\hline With both regressors & & & \\
Med båda regressorer & & & \\
$\quad$ For temperature: & -0.180 & 0.2572 & 0.485 \\
$\quad$ For precipitation: & -0.666 & 0.4107 & 0.105 \\
\hline With only temperature & -0.475 & 0.1881 & 0.012 \\
Med bara temperatur & & & 0.004 \\
\hline With only precipitation & -0.865 & 0.3001 & \\
Med bara nederbörd & & & \\
\hline
\end{tabular}


peared alone in separate models, colinearity obviously was eliminated. Then, there were significant results in both cases. With the long-winter temperature in the model, the p-value was 0.012 and with the long-winter precipitation, the $\mathrm{p}$-value was 0.004 . When applying the short-winter explanatory variables, the p-values were 0.014 and 0.010 , respectively. The use of simpler models with only one regressor generally leads to larger error terms. In this case, it turned out that the simplification did not cause as great a problem as the colinearity (a well-known problem resulting in bad precision of the estimates). For both regressors, the estimates of the parameters were negative. This means that an increase in temperature lessens the probability of return. The same applies to precipitation (see Figure $3 \mathrm{a}$ and $3 \mathrm{~b}$.)

Since there was colinearity, yet another model was applied where only the interaction term was included, i.e., the product of the two regressors formed one explanatory variable. In this case, the p-value was 0.008 and the estimate of the parameter hade a negative value. The interpretation is that the combination of low values of both regressors predicts a higher probability of return than a combination of high values. The latter may be followed by feeding difficulties such as those caused by ice glazing (see below). However, the difference in importance for the two regressors cannot be judged from this result.

\section{Final remarks}

It is generally known that the Treecreeper is vulnerable to adverse weather during winter, especially when rain or wet snow is followed by hard frost

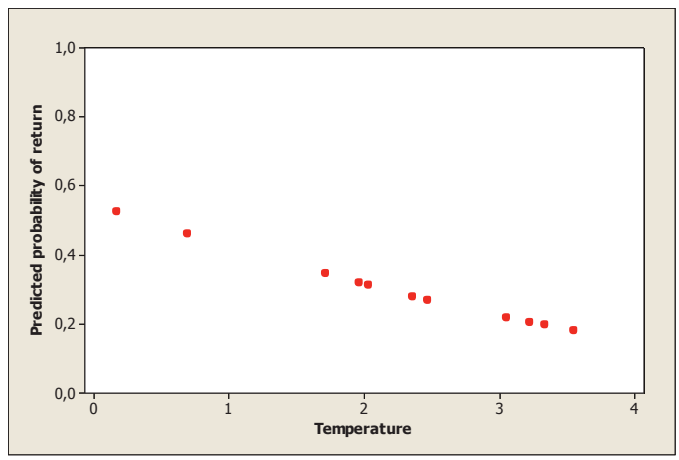

Figure 3a. Estimated probability of return as a function of temperature. Calculations from a logistic regression model. Skattning av sannolikheten för återkomst. I beräkningarna har inverkan av temperatur tagits med där en logistisk regression har använts. resulting in ice glazing on tree trunks and branches, which causes major difficulties for a foraging bird (e.g. Marchant et al. 1990, Peach et al. 1995). The Treecreeper seems best adapted to constant and moderately cold winters with or without snow. This assumption is supported by the fact that the winters during which the three midwinter months (December, January and February) had temperature means below zero, varying from -2.0 to -4.7 , were followed by exceptionally high return rates (1996 and 2003, Table 1). On the other hand, the infrequent extremely cold winters are known to dramatically increase the winter mortality of the forest resident passerines including the Treecreeper (Marchant et al. 1990).

The occasionally dramatic fluctuations in population numbers (Figure 2) might indicate the impact of a strong winter mortality factor. Perhaps the technique chosen to characterize the winter weather (see Study area and methods) is not refined enough to clearly reveal the connection between winter severity and the disappearance rate of the wintering birds. Unfortunately, the percentage change between years in the size of the breeding population cannot be estimated by means of ringing in the same way as the return rate of the adult females (see above). The reason is that very few of the ringed and surviving fledglings return to breed in the study area. Only four out of about 185 ringed female fledglings (assuming an equal sex ratio) returned to the study area and bred as yearlings, a negligible figure as about $70 \%$ of the breeding females every year are new and recruited from elsewhere. Moreover, other factors may also have impact on the breeding population size, such as freezing and thawing episodes, periods of high

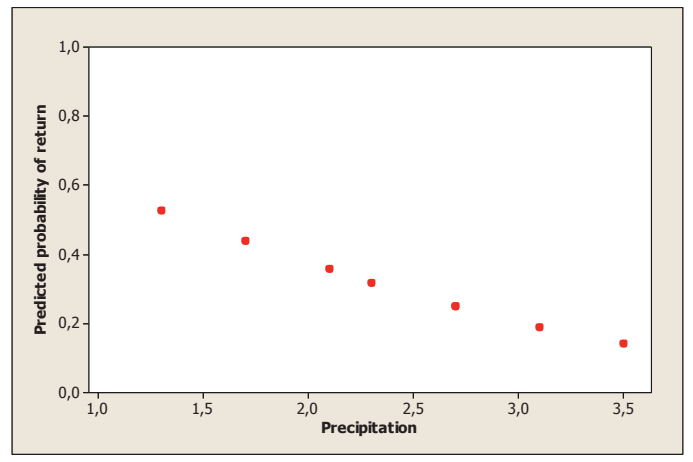

Figure $3 b$. Estimated probability of return as a function of precipitation. Calculations from a logistic regression model. Skattning av sannolikheten för återkomst. I beräkningarna har inverkan av nederbörd tagits med där en logistisk regression har använts. 
predation pressure and preceding seasons with poor production of fledglings or food organisms.

\section{Acknowledgements}

Financial support was received from the Royal Society of Arts and Sciences in Gothenburg.

\section{References}

Ahlén, I. \& Nilsson, S.G. 1982. Samband mellan fågelfauna och biotopareal på öar med naturskog i Mälaren och Hjälmaren. Vår Fågelvärld 41: 161-184.

Enemar, A. 1995. Incubation, hatching, and clutch desertion of the Treecreeper Certhia familiaris in south-western Sweden. Ornis Svecica 5: 111-124.

Enemar, A. 2009. First, second and replacement broods in the breeding biology of a Treecreeper Certhia familiaris population. Ornis Svecica 19: 97-114.

Glutz von Blotzheim, U.M. \& Bauer, K.M. 1993. Handbuch der Vögel Mitteleuropas Bd 13/II. AULA-Verlag, Wiesbaden.

Kluijver, H.N. 1951. The population ecology of the Great Tit, Parus major L. Ardea 39: 1-135.

Kuitunen, M. \& Helle, P. 1988. Relationship of the Common Treecreeper Certhia familiaris to edge effect and forest fragmentation. Ornis Fennica 65: 150-155.

Marchant, J.H., Hudson, R., Carter, S.P. \& Whittington, P. 1990. Population trends in British breeding birds. British Trust for Ornithology. Tring.

Newton, I. 1998. Population Limitation in Birds. Academic Press Limited. London.

Ottvall, R., Edenius, J., Elmberg, J., Engström, H., Green, M., Holmqvist, N., Lindström, Å., Pärt, T. \& Tjernberg, M. 2009. Population trends for Swedish birds. Ornis Svecica 19: 117-192.

Ottosson, U., Ottvall, R., Elmberg, J., Green, M., Gustafsson, R., Haas, F., Holmqvist, N., Lindström, Å., Nilsson, L., Svensson, M., Svensson, S. \& Tjernberg, M. 2012. Fåglarna i Sverige - antal och förekomst. SOF, Halmstad.

Perch, W., du Feu, C. \& McMeeking, J. 1995. Site tenacity and survival rates of Wrens Troglodytes troglodytes and Treecreepers Certhia familiaris in a Nottinghamshire wood. Ibis 117: 497-507.

Perrins, C.M. 1979. British Tits. Collins, London.

Schönfeldt, M. 1983. Beiträge zur Ökologie und zum intraspezifischen Verhalten der Baumläufer Certhia familiaris und C. brachydactyla in Eichen-Hainbuchenwäldern unter dem Aspect der erhöhten Siedlungsdichte durch eingebrachte Nisthöhlen. Hercynia N.F. 20: 290-311.

Schwerdtfeger, O. 1987. Gesangaktivität und Siedlungsdichte beim Waldbaumläufer und Gartenbaumläufer (Certhia familiaris u. C. brachydactyla). Beitr. Naturk. Niedersachsens 40: 222-226.

SMHI 1981-2009. Väder och Vatten.

Steinfatt. O. 1939. Das Brutleben des Waldbaumläufers Certhia f. familiaris. Mitteilungen des Vereins sächsischer Ornithologen 6: 1-18.

\section{Sammanfattning}

\section{Studieområde och metoder}

Under senare decennier har en rad studier utförts över trädkryparens häckningsbiologi strax söder om Göteborg, närmare bestämt i Gunnebo slottspark med närmaste omgivningar mellan Mölndal och Pixbo (e.g. Enemar 1995, 2009). Terrängen täcks av lövskog som lämnar 10-15\% öppen terräng, mestadels i form av betesmark. Omkring en fjärdedel av skogsmarken består av odlad granskog. För trädkryparstudierna har 300 specialholkar för arten, s.k. häckningsfickor, satts upp i ca brösthöjd på trädstammarna. Av häckningsfickorna är 205 samlade i en $2,7 \mathrm{~km}^{2}$ stor provyta, där antalet fickor och i möjligaste mån deras placering har hållits konstant under 28 år (1982-2009). Häckningsfickor på avverkade och omkullblåsta träd har flyttats till närmaste lämpliga trädstam. En skiss över denna provyta med häckningsfickornas placering markerade presenteras i Figur 1. Det är antalet häckande trädkrypare i denna provyta som årligen bestämts så som beskrivs nedan.

Häckningsfickan tillverkas av ett rektangulärt stycke underhållsfri takpapp, som nubbas fast på trädstammen sedan den klämts ihop något, varmed ett utrymme lämnas för trädkryparboet mellan stammen och pappen. På vardera sidokanten snittas en öppning för fågeln för passagen till och från boet. Eftersom den större hackspetten gärna hackar upp ett hål mitt på fickan och rövar boet kan förlusterna ibland bli besvärande stora. Detta förhindras effektivt om man täcker fickan med ett stycke perforerad aluminiumplåt, vilket bör göras så snart värpningen börjat. Då är uppenbarligen trädkryparhonan så starkt bunden vid boet att den plötsligt uppträdande plåtrustningen inte orsakar övergivning.

En häckande småfågelpopulation inom en provyta ändrar sin storlek och sammansättning under hela häckningstiden. Frågan är vad som skall räknas som årets beståndsstorlek. Skall dess fluktuationer under årens lopp följas, måste beräkningsmetoden hela tiden vara densamma. I denna undersökning har vi räknat alla kullar vars värpning påbörjades inom 21 dagar efter vårens först värpta ägg i provytan ("21-dygnskullarna"). Därmed undviker man praktiskt taget helt risken att dubbelräkna någon hona, dvs. sådana som förlorat sin första kull och sedan efter några dagars uppehåll häckar på nytt $i$ en annan häckningsficka inom provytan. Denna metod att undvika dubbelräkning har testats de år, då alla honor färgringmärkts. Det visade sig att endast $3 \%$ (6 av 180) av de inräknade häckningarna 
bland "21-dygnskullarna" var omläggningar.

Alla häckande honor ringmärktes säsongerna 1995 till 2009 med undantag för 2004, 2006 och 2007. Varje hona försågs med en unik kombination av tre färgringar och en aluminiumring.

Väderdata (temperatur och nederbörd) är hämtade från SMHI:s månadsskrift "Väder och vatten" (SMHI 1981-2009). Data från väderstationen vid Säve flygplats har använts. Dygnsmedeltemperaturen är vid Säve i stort sett densamma som i provyteområdet (Enemar 1997). Då vintervädrets inverkan på trädkryparnas överlevnad har studerats, har två vinterlängder använts, dels en midvinterperiod (november - februari), dels en helvinterperiod (oktober - mars).

\section{Populationsstorlek och täthet}

Av diagrammet i Figur 2 framgår att det häckande beståndets (21-dygnsbeståndets) storlek varierat avsevärt mellan säsongerna med 5 par som minsta och 21 par som största bestånd. Medelantalet för de 28 åren är $14 \pm 4,2$ par. Trots de emellanåt häftiga antalsändringarna mellan åren har provytans bestånd lyckats hålla sig långsiktigt stabilt. Enligt de landsomfattande häckfågeltaxeringarna (Ottvall et al. 2009) har dock det svenska trädkryparbeståndet minskat under 10-årsperioden fram till 2006.

Vad gäller populationsvariationernas storlek är det landsomfattande beståndet och provytans population samstämmiga. Deras CV-värden är 25\% resp. 30\%. De ligger alltså nära varandra. (CV uttrycker beståndsvariationens storlek i procent av beståndsstorleken.)

Trädkryparen är ju känd som en förhållandevis glest häckande art. I provytan har tätheten som väntat varierat stort, nämligen från 1,9 till 7,8 par/ $\mathrm{km}^{2}$, vilket betyder en medeltäthet på ca $5 \mathrm{par} / \mathrm{km}^{2}$ $\left(5,1 \pm 1,86 \mathrm{par} / \mathrm{km}^{2}\right)$. En häckningstäthet på denna nivå har rapporterats från andra lokaler i södra Sverige. Den rika tillgången på häckningsfickor och på lämplig miljö har uppenbarligen inte lockat fler par till häckning än normalt. En häckande beståndstäthet av samma storleksordning har rapporterats från många håll i Europa. Dock har uppsättning av trädkryparholkar i överskott åtföljts av en betydande ökning av häckningstätheten i ett par tyska undersökningar.

\section{Vintervädrets inverkan på den häckande populationens storlek}

Som den stannfågel trädkryparen är, har den att härda ut en lång vinter i väntan på nästa häcknings- säsong. Eftersom arten visar sig vara väderkänslig även under häckningen, då honorna kan göra en paus i äggläggningen eller överge äggkullar och även små boungar under kyliga och regniga perioder, kan man förvänta sig att den ökade dödligheten under särskilt bistra vintrar åtföljs av minskat antal häckande par påföljande vår. Sambandet mellan medeltemperatur och medelnederbörd under såväl november - februari som oktober - mars och den påföljande beståndsstorleken under häckningssäsongen har undersökts statistiskt. Någon bekräftelse på ett signifikant samband mellan vintervädrets stränghet och det häckande beståndets storlek erhölls icke, kanske främst beroende på att det studerade trädkryparbeståndet är förhållandevis litet samt på att de två väderfaktorerna, temperatur och nederbörd, samvarierar. Dessutom påverkas antalet häckande även av andra faktorer såsom antalet flygga ungar föregående säsong, tillgången på näring och förekomsten av predatorer.

\section{De individuella trädkryparhonornas återkomst}

Eftersom de häckande honorna färgringmärktes åren 1996 till 2009 (undantag 2004, 2006 och 2007) kunde vi också studera vinteröverlevnad för enskilda honor. Eftersom antalet ringmärkta honor vid häckningssäsongens slut var känt liksom antalet återvändande häckare nästa säsong kunde återkomstfrekvensen beräknas. Resultatet presenteras i Tabell 1. Sambandet mellan frekvensen återvändande honor och väderförhållandena under vintern undersöktes statistiskt på olika sätt. Testas temperaturen och nederbörden var för sig erhålls ett signifikant samband i båda fallen mellan frekvensen återkomster och de båda väderfaktorerna. Med sjunkande temperatur och minskande nederbörd ökar frekvensen återkomster. Blir det varmare och regnigare drabbas uppenbarligen trädkryparna av större övervintringsförluster. Detta kan till en del bero på att vätan ger upphov till isbark när temperaturen rör sig kring 0-läget, något som försvårar näringsfånget och orsakar förluster.

Det är dock känt att även vintrar med långa perioder med mycket sträng köld kan slå ut en stor del av de övervintrande småfåglarna inklusive trädkryparna. Vissa arter kan försvinna helt från stora områden. Bäst för trädkryparnas överlevnad torde vara en vintertemperatur som konstant håller sig ett måttligt antal grader under noll i kombination med ingen eller ringa nederbörd i form av snö. 